\title{
Production of Al-Si-Fe-X alloys by powder metallurgy
}

Andrea Školáková1, Pavel Novák ${ }^{1}$, Dalibor Vojtěch ${ }^{1}$, Tomáš František Kubatík ${ }^{2}$

${ }^{1}$ Institute of Chemical Technology, Prague, Department of Metals and Corrosion Engineering, Technická 5, 16628 Prague 6, Czech Republic, E-mail: SkolakovaA@seznam.cz

${ }^{2}$ Institute of Plasma Physics AS CR, v.v.i., Za Slovankou 1782/3, 18200 Prague 8, Czech Republic, E-mail: kubatik@ipp.cas.cz

The aim of the present work was to study the effect of chromium and nickel on the Al-Si alloy, which contained certain amount of iron, and to describe, how these alloying elements affect mechanical properties at room and elevated temperature. Nickel and chromium were chosen as alloying elements due to the low solubility and diffusivity in aluminium matrix, which improve mechanical properties and thermal stability at elevated temperature. Measurements were made on the cast alloys, rapidly solidified alloys and compact alloys. Rapidly solidified alloys were produced using a melt spinning process. Compaction of prepared ribbons was carried out using Spark Plasma Sintering. The microstructure of the products was examined using optical microscopy and X-ray diffraction. Vickers hardness was measured to determine mechanical properties.

Key words: aluminium alloys, rapid solidification, melt spinning, Spark Plasma Sintering

\section{Acknowledgement}

This research was financially supported by Czech Science Foundation, project No. P108/12/G043.

\section{References}

[1] LAVERNIA, E. J., AYERS, J. D., SRIVATSAN, T. S. (1992). Rapid solidification processing with specific application to aluminium alloys. In: International Materials Reviews, Vol. 37, pp. 1-44. Maney Publishing, UK.

[2] UZUN, O., KARAASLAN, T. GOGEBAKAN, M. KESKIN, M. (2004). Hardness and microstructural characteristics of rapidly solidified Al-8-16 wt. \% Si alloys. In: J. Alloys Compd., Vol. 376, No. 1-2, pp. 149-157. Elsevier, Netherlands.

[3] ÜNLÜ, N., GENÇ, A., ÖVEÇOĞLU, M. L., LAVERNIA, E. J., FROES, F. H. (2002). Microstructural evolution during annealing of the melt-spun ternary hypoeutectic Al-7.6Si-3.3Fe (in wt.\%) alloy. In: J. Alloys Compd., Vol. 343, No. 1-2, pp. 223-233. Elsevier, Netherlands.

[4] JOHANSEN, I., ROVEN, H. J. (1994). Mechanical properties of a rapidly solidified Al-Si-Ni-Mn. In: Material Science and Engineering, A, Vol. 180, No. 1, pp. 605-608. Elsevier, Netherlands.

[5] XU, C. L., WANG, H. Y., QIU, F., YANG, Y. F., JIANG, Q. C. (2006). Cooling rate and microstructure of rapidly solidified Al-20 wt. \% Si alloy. In: Materials Science and Engineering, A, Vol. 417, No. 1-2, pp. 275-280. Elsevier, Netherlands.

[6] ZHANG, Z., LIU, Z., LU, J., SHEN, X., WANG, F., WANG, Y. (2014). The sintering mechanism in spark plasma sintering - Proof of the occurrence of spark discharge. In: Scripta Materialia, Vol. 81, pp. 56-59. Elsevier, Netherlands. 